\title{
Casarão Amália Noll: An architectural mosaic of the immigration in southern Brazil
}

\section{Casarão Amália Noll: Um mosaico arquitetônico da imigração no sul do Brasil}

DOI: 10.46932/sfjdv2n1-006

Received in: November 1st, 2020

Accepted in: December 30th, 2020

\author{
Pablo Cesar Uez \\ Squadro Arquitetura e Engenharia Ltda., Caxias do Sul, Brazil \\ E-mail: pablouez@gmail.com \\ Cristiane Rauber \\ Squadro Arquitetura e Engenharia Ltda., Caxias do Sul, Brazil \\ E-mail: arqcristianerauber@ hotmail.com \\ Juliana Betemps Vaz da Silva \\ Squadro Arquitetura e Engenharia Ltda., Caxias do Sul, Brazil \\ E-mail: juliana@julianabetemps.com.br
}

\begin{abstract}
At the end of the XXI century, a big immigration phenomenon happened in the south of Brazil, when thousands of European decided to leave their native country to look for new and unexplored lands. The material and immaterial multicultural patrimony generated by them remains as history legacy from the European colonization (Portuguese, German and Italian), and many other ethnic groups developed and raised the people of Rio Grande do Sul. In these work we are going to deal particularly with the heritages from the peoples who debarked at Guimarães' harbor, in São Sebastião do Caí, Rio Grande do Sul, Brazil, that were spread out through communities as the Rio Branco road was opened. This road has an extension of 250 Kilometers moreover, nowadays, it passes through one of the most important industrial developed regions of Brazil. Even so, we can still find through this road many architectonic exemplars of the immigration period, as well as descendants residing on its banks.

The Casarão Amália Noll, in Feliz city, is one of these exemplars of the survival architecture from the past period. This building shows distinct steps and constructive techniques, furthermore we can identify in one single room the presence of the characteristics from the Portuguese, German and Italian architecture. In 2015, the construction finds itself in low state of preservation, when at the time begins the woks of cadastral surveys, diagnosis of pathologies and proposal of intervention.

The present article aim to show the proposed solutions for the first stage of architectonic intervention, in which we opted for the ruin stabilization and for the architectonic volumes restoration. At the new restored space will work a traditional German brewery, called Biergarten of Amália, beyond the museum of craft beer, immaterial heritage brought by the Germany people to the region.
\end{abstract}

Keywords: Heritage buildings, Rehabilitation, Imigration

\section{RESUMO}

Um grande fenómeno imigratório aconteceu no sul do Brasil no final do século XIX, quando milhares de europeus decidiram ir em busca de novas terras, ainda inexploradas. O patrimônio multicultural material e imaterial por eles produzido permanece como um legado histórico da colonização europeia (portuguesa, 
alemã e italiana), e várias foram as etnias que deram origem ao povo rio-grandense. Neste trabalho trataremos particularmente das heranças dos povos que desembarcaram no Porto de Guimarães, em São Sebastião do Caí, Rio Grande do Sul, Brasil, e que foram distribuindo-se em comunidades a medida em que abriam a Estrada Rio Branco. Esta estrada tem extensão de $250 \mathrm{~km}$ e hoje corta uma das regiões industrialmente mais desenvolvidas do Brasil. Ainda assim, encontramos ao longo desta via varios exemplares arquitetônicos da época da imigração, bem como descendentes de imigrantes residindo às suas margens.

O Casarão Amália Noll, na cidade de Feliz, é um destes exemplares. Apresenta distintas etapas e técnicas construtivas, sendo possível identificar num único imóvel a presença das características da arquitetura portuguesa, alemã e italiana. Em 2015, a edificação encontra-se em precário estado de conservação, quando então começam os trabalhos de levantamento cadastral, diagnóstico de patologias e proposta de intervenção.

O presente artigo tem por objetivo apresentar as soluções propostas para a primeira etapa de intervenção arquitetônica, na qual optamos pela estabilização da ruína e a recomposição de volumes arquitetônicos. No novo espaço funcionará uma cervejaria tipicamente alemã, denominada Biergarten da Amália, além do Museu da Cerveja Artesanal, patrimônio imaterial trazidos pelos alemães à região.

Palavras-chave: Patrimônio edificado, Reabilitação, Imigração.

\section{INTRODUCTION}

From the middle of the 19th century, the colonization process in the south of the country intensified, due to the immigration policy in force in the imperial and republican period. Through this policy, the imperial government intended to populate the vacant lands of the Northeast of Rio Grande do Sul with the installation of free labor, the regime of small property, subsidiary agriculture, white labor, ensuring hegemony in the border regions. This initiative favored economic development as the work regime changed, strengthened by the installation of agricultural colonies, governed by the Land Law of 1850. The occupation of land by European emigrants and the immigration policies that supported the colonization process caused that the establishment of agricultural establishments was successful. The structuring of agricultural colonies in southern Brazil reflects the form of land organization.

Cultural reflexes of this process are still strongly perceived today in the different regions of Rio Grande do Sul, a state located in the extreme south of Brazil. The miscegenation of different cultures is present in the constructions, in the stories, in the knowledge and actions of the descendants of the immigration process that, with a lot of work, formed one of the most prosperous regions of Brazil.

\section{IMMIGRATION IN SOUTHERN BRAZIL}

The colonization in Rio Grande do Sul was made essentially by Azoreans, Germans and Italians. According to the order of the Overseas Council of Portugal, on June 22, 1729, colonization was carried out with colonies of Azorean origin, completed with foreign couples, provided they were not of English, 
Dutch and Castilian origin. D. João VI and D. Pedro I, during the German colonization phase and later D. Pedro II, during the Italian colonization phase, did not raise any objections, facilitating this initiative. The initial colonization program was called Walkerfield, which constituted the

"distribution of a lot of land, tools, animals, seeds to farmers, payment of modest subsidies for the food of the colonists in the first year of establishment" (PELLANDA, Ernesto).

In 1848, the General Government had granted 36 square leagues of land as a donation for the colonization of European emigrants who occupied the plains of the Valleys of Rio Caí and Rio dos Sinos. The Provincial Government of Rio Grande do Sul requested more vacant lands from the plateau, covered with virgin forest, that is, two territories of four leagues in frame, equivalent to 32 square leagues to continue the colonization work. These lands were located in the region of the upper hills of the northeast range of the Province of São Pedro do Rio Grande do Sul, located between the basins of the rivers Caí, Antas and Taquari, with the geographical limits in São João do Montenegro, São Sebastião do Caí, Taquara do Mundo Novo and São Francisco de Paula de Cima da Serra. The Provincial Government had the intention of, in addition to implanting new agricultural colonies, with European labor, opening roads that would allow the connection of the plateau with the Central Depression.

\section{THE RIO BRANCO ROAD}

The colonial road, Estrada Visconde do Rio Branco, which started at Porto dos Guimarães, in São Sebastião do Caí, gave access to Colônia Caxias until Vacaria, and was built between the years 1877 to 1907. The historical approaches allow us to affirm that the Estrada Rio Branco was made in two stages: the first, from São Sebastião do Caí to Caxias do Sul, inaugurated in 1884, and the second, from Caxias do Sul to Vacaria, from 1897 to 1903. In the phase of colonial production, Estrada Rio Branco was the only way of connecting transport with the economic centers of the time. The existence of means of communication with other municipalities was considered one of the main conditions for the emancipation of the colonies. 
Figure 1: Guimarães Port in São Sebastião do Caí in full swing at the end of the 19th century

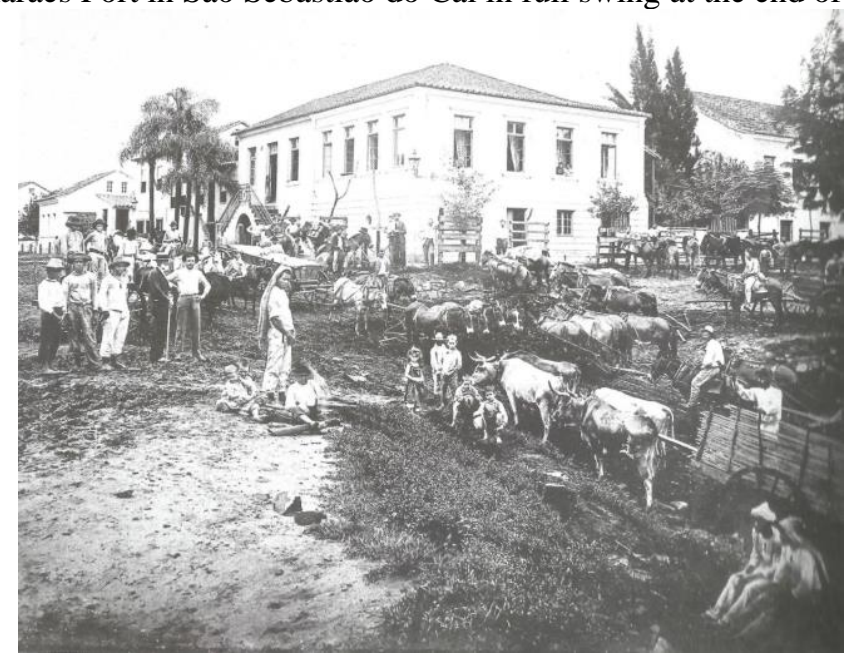

The intention of building the Rio Branco Road was to unify the colonies with the cities, the consumption centers of the late 19th century, such as Porto Alegre, Montenegro, São Paulo and Rio de Janeiro. In these territories, elements of initial industrialization processes are combined with traditional elements of rural cultures.

One of the striking elements along the route of Estrada Rio Branco is the presence of a material and immaterial historical heritage, of German culture in the Vale do Caí; Italian culture, in the Nova Palmira section, along Estrada do Imigrante, in Terceira Légua, to Ana Rech, in Caxias do Sul; and the stretch of Luso-Brazilian culture, from Vila Seca to Ponte dos Korff, in Criúva.

The preservation and enhancement of the cultural elements of Estrada Rio Branco in an integrated manner constitute a comparative and competitive advantage, since the landscape diversity (valley, mountains and fields above the mountain) and cultural diversity (habits and customs of three cultures ) translate into potential for attractions and tourist products.

"The territory involved is composed of several spaces of phenomena, which place the need for a sectorial and spatial resizing as a new form of local development. The sectoral perspective tends to be replaced by the territorial perspective, with the specific potential of each location as a central element". (Brambatti, 2015)

\section{THE CASARÃO AMÁLIA NOLL}

Amália was a descendant of German immigrants who never married.

"With the death of her parents, she took over the mother house of the Ruschel family, at the time
a beautiful property, built by immigrant Sebastião Ruschel. Jacob Ruschel's business house was
located on the site. With his early death, Amália took over the property, as she lived there. For
many years she managed a small dry and wet trade. Later, she rented some pieces for different
purposes, (...) It was there that the Happy Rural Union was first installed. But what about the great
hall where the business house once functioned? For many years he transformed the place into a
ballroom, serving people who were not members of the Sociedade Cultural de Feliz and to offer
yet another place of entertainment. But Amália followed the evolution of the times. And it was 
then that she thought of providing the people of Feliz with fun that only existed in big cities. It imported a film projection machine directly from Germany. It was a modern and famous Bauer. This was in the mid-1960s. The sensation was great all around. Who didn't come to the "Malche" cinema? Watch the films by Teixeirinha, Tarzan, Mazzaropi, and the famous Noviça Rebelde and Sissi's scripts, A Empress. "(1)

The Casarão Amália Noll is located in a privileged area of the city, in front of the River Caí and the century-old iron bridge imported from Belgium, opened in 1900. These three items are anchors of the future Largo dos Imigrantes, an urbanization project by the City Hall that will mix history, environmental protection, architectural heritage, leisure and culture, established on the path that in the past was the route of immigration. Concerned with the preservation of its architectural heritage, especially the Amália Noll Casarão, the City Hall has taken control initiatives, such as the acquisition and listing of historic sites.

\subsection{THE REGISTRATION SURVEY}

In 2014, work begins on the cadastral survey of the building, at a time when the property is already with numerous pathologies, in a precarious state of conservation. The objective is to recover the building, returning the old cinema to Feliz's society, in addition to the creation of the Amália Biergarten and the Museum of Craft Beer.

"The valorization of the territory and the reframing process begin with their knowledge (inventory,
oral memory, formation of photographic archives), then continue with the training of local
entrepreneurs for integrated and sustainable actions between culture, territory and tourism
(training), interacting with various actors involved, such as local communities and public
authorities."(Brambatti, 2015)

Casarão Amália Noll is composed of a set of buildings, with different architectural characteristics, built at different times, from the end of the 19th century, with the arrival of German immigrants to the region. Over the years it has housed various activities, including a dry and wet warehouse, cinema, ballroom, consulting rooms and housing. 
Figure 2: Casarão Amália Noll front view

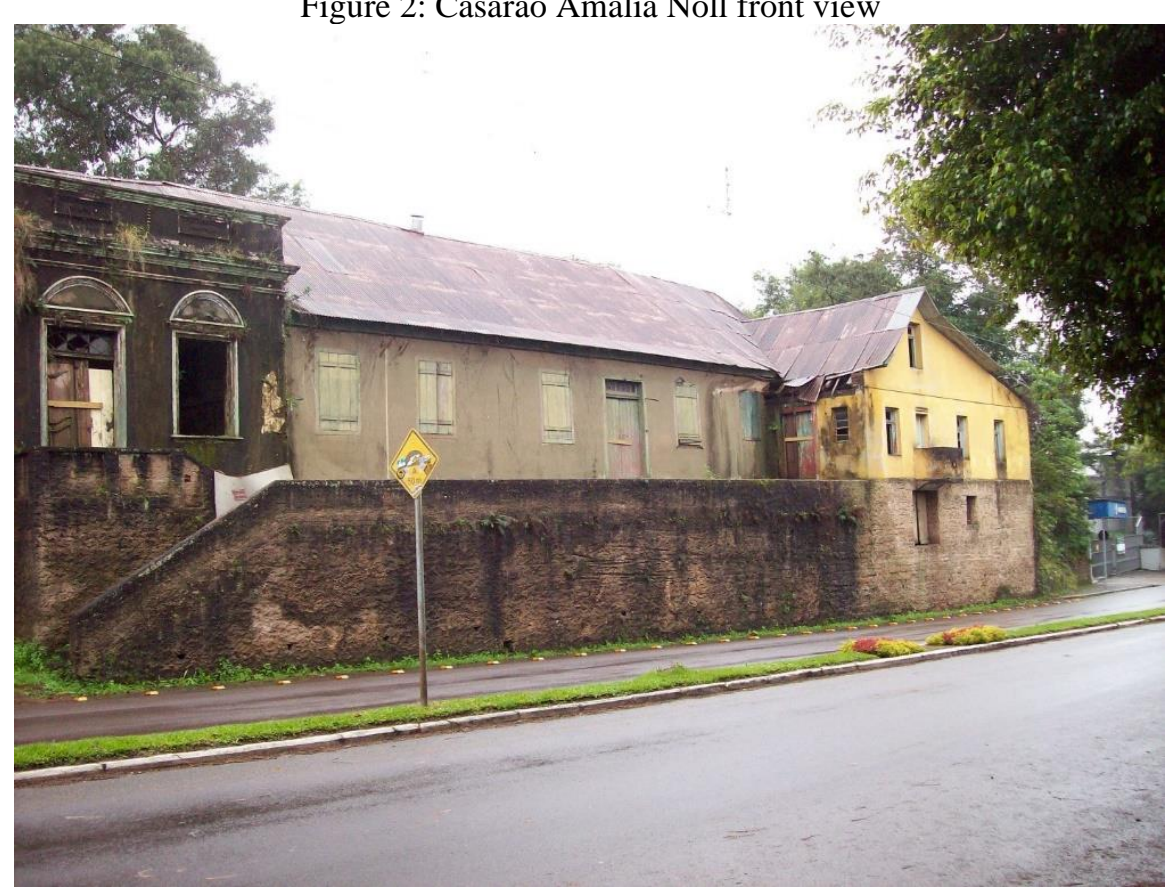

The set can be divided into three blocks:

The block on the left is composed of two buildings, both with characteristics of eclectic architecture, with basement and first floor. The front building has stone masonry made of sandstone, floor structure, wooden floor and roof, wooden frames, lime and sand mortar plaster and stucco adornments. It has friezes, cornices, frames and glasses for ventilation of the basement. The same elements are repeated on the back, but the masonry is made of solid bricks. Inside both, the walls are structured with wood and solid bricks. You can see marbled paintings, like scales. They are in a precarious state of conservation, with the back part in ruins. Cracks, downward humidity and infestation by woodcutters, fungi and lichens are noted.

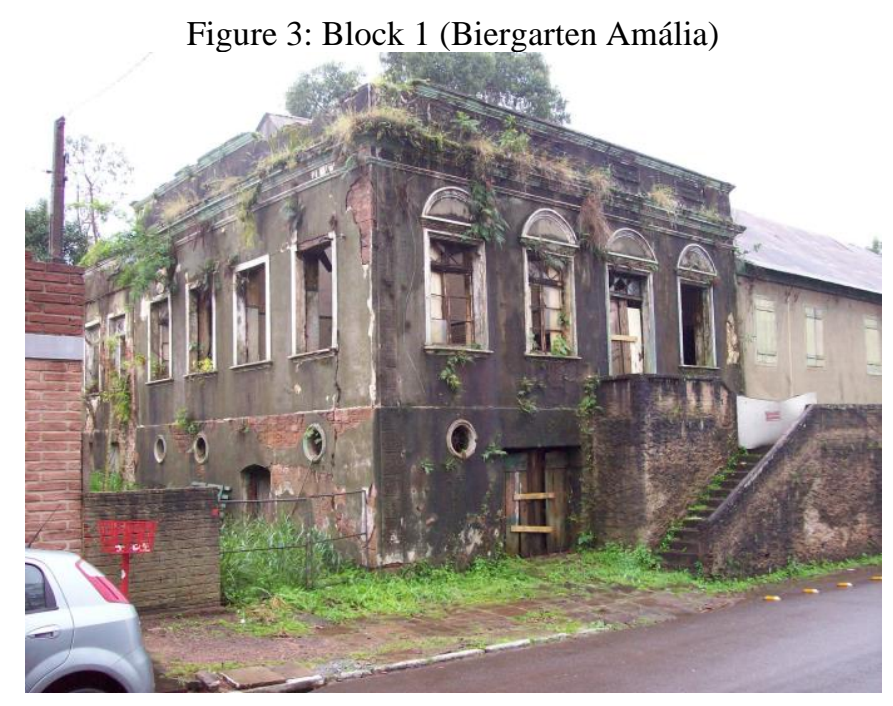


The central block is half-timbered, structured with thick pillars and wooden beams and closed with solid bricks. The large span is structured with the aid of metallic cabling (cover), coffin-like lining, floor and wooden structure. All construction elements are in a precarious state of conservation. The presence of termite and borer nests is noticed. Also, at the rear of the central block, there is a constructive addition in solid brick masonry, wooden floor and roof structure.

Figure 4: Block 2, half-timbered, old (and future) cinema
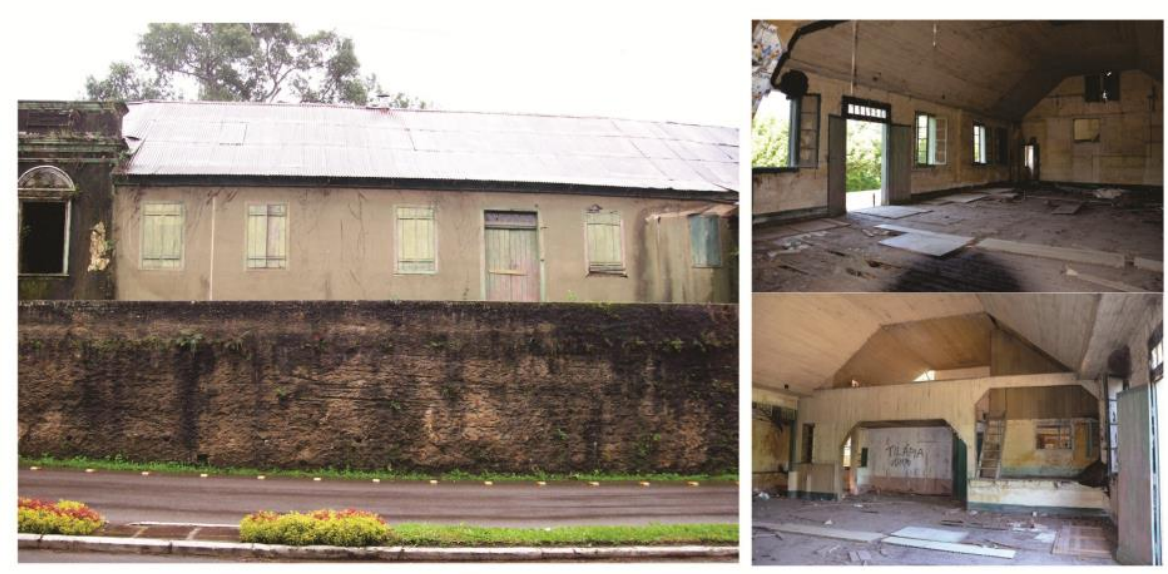

The block to the right of the set consists of two buildings. At the front, the building is in a poor state of repair and has a basement, ground floor and attic in solid brick masonry and part of it in wood with a joint. It has a half-timbered wall, possibly reminiscent of some previous building. It communicates with the central block, being separated from it only by a wooden wall. A small internal courtyard separates the two buildings on this block. At the rear is a single storey building, with traces of Portuguese colonial architecture, thick stone walls, arches hand-plastered with lime mortar, beams of solid sandstone stones in the windows, doors and sills. This would possibly be the oldest part of the set.

Figure 5: Block 3, Portuguese colonial architecture

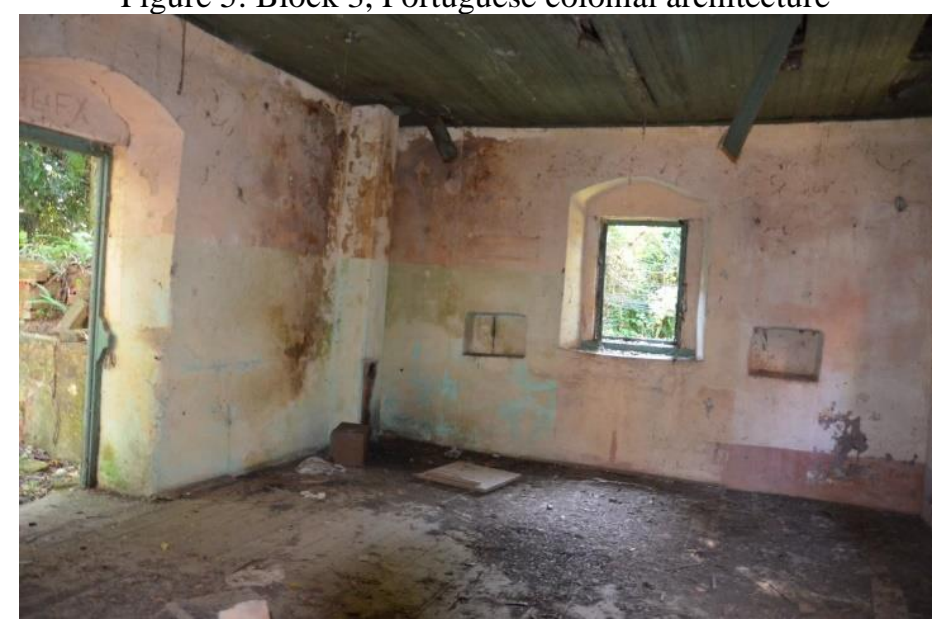


Still inside the listed site, at the back of the lot, we find a stone and brick oven, cistern and several species of native flora.

\subsection{THE STRUCTURAL REPORT}

The main factor that caused the pathological manifestations evidenced in this building was the lack of maintenance. Allied to this, the excess of moisture present in the building provided the ideal environment for vegetation growth, causing the roots to penetrate through the masonry joints, causing cracks. Moisture also caused the wood to rot in practically the entire building. From a thorough survey on the spot, the prognosis of pathological manifestations was developed. The building is already in a high degree of deterioration, and much of the building is already collapsing. The tendency is that the building will collapse in its entirety.

In view of all the data collected and exposed so far, with the interrelationships between the objective information collected, through logical reasoning and the light of mathematical and physical knowledge applied in engineering, the opinion suggests that the removal of the roof of the building to avoid sudden collapse, which can damage the adjacent masonry and also put the lives of people who transit near the building at risk. The entire support structure of the floor, as well as the floor itself, must be completely removed and rebuild, given the high degree of deterioration it presents. The external walls must undergo a thorough restoration process, as many walls have been affected by vegetation, causing the walls to crack due to the roots. The internal walls of block 1 of the building (Figure 2) must be completely removed, no longer being able to be reused. All wooden walls must be replaced, as they present a high degree of deterioration.

\subsection{THE REHABILITATION PROJECT (BLOCK 1)}

\footnotetext{
"Spontaneity in the use of heritage in the activity of tourism constitutes a risk, since the use and appropriation of this heritage without the proper planning, promotion and regulations, can mean the rapid destruction of heritage and the transformation and destruction of cultural traits, which may they simply become simulacra, exposing themselves to ridicule, with short duration". (Brambatti, 2015)
} 
Figure 6: Intervention proposal

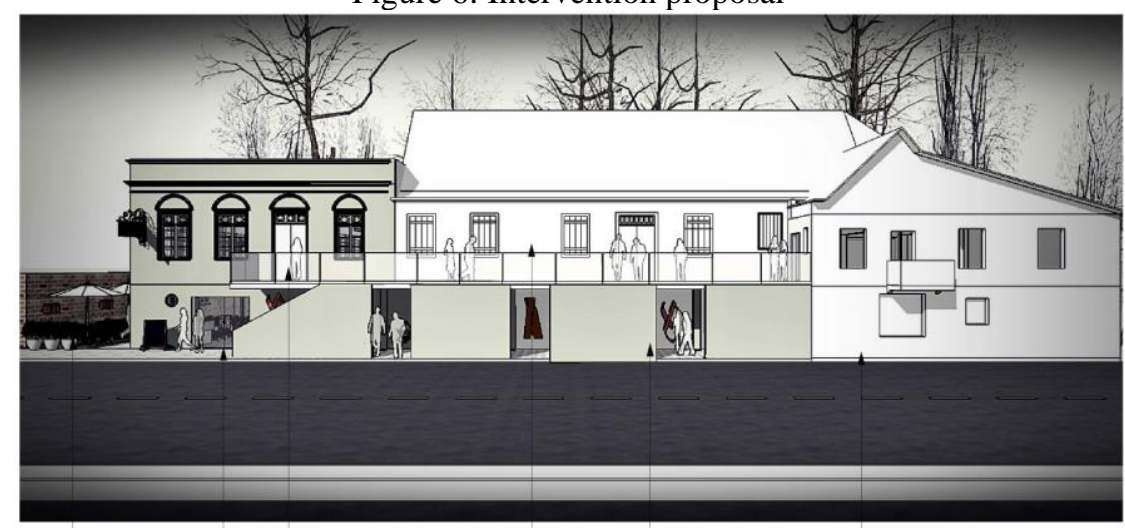

ESTAR EXTERNO

PORTA DE ACESSO AO

BIERGARTENEAO
MUSEU DA CERVEJA

PORTA DEACESSO SECUNDÁRIO
AO MUSEU DA CERVEJA

BLOCO DESTINADO A REABLLTTAÇ̄o DO CINEMA (FASE 2)

TÚNEL DE PASSAGEM COM JANELAS DE OBSERVACĀo.

促 RELATANDO ATRAVÉS DESTE A HISTÓRIA DO CASARÁO AMÁLIA NOLL

ELEVADOR QUE DÁ ACESSO AO SEGUNDO PAVIMENTO ELEVADOR QUE DA ACESSO AO SEGUNDO PAVIMENTO
(FOYER DO CINEMA, SACADA DE OBSERVAÇAO E MUSEU DA CERVEJA).
PROJETADO NA FASE 2 .

The general objective of the Casarão Amália Noll Rehabilitation Project is to restore the historic site installed on the route that was once the route of immigration to the heights of Serra Gaúcha, promoting the stabilization of the ruin and the restoration of architectural volumes; archaeological prospecting; reactivation of the old cinema existing on the site; installation of the Feliz Cultural Foundation and the Happy German Folk Dance Group; offering multipurpose cultural rooms and exhibition space for public use; creation of a typical German brewery in the internal garden, to be called Biália da Amália; outdoor exposure of the vine seedling that is considered by some historians as the matrix of viticulture that came to thrive in Serra Gaúcha; installation of access elements to open spaces and exhibition elements that will tell the story of Cerveja Artesanal.

The first stage of intervention will take place in block 1 .

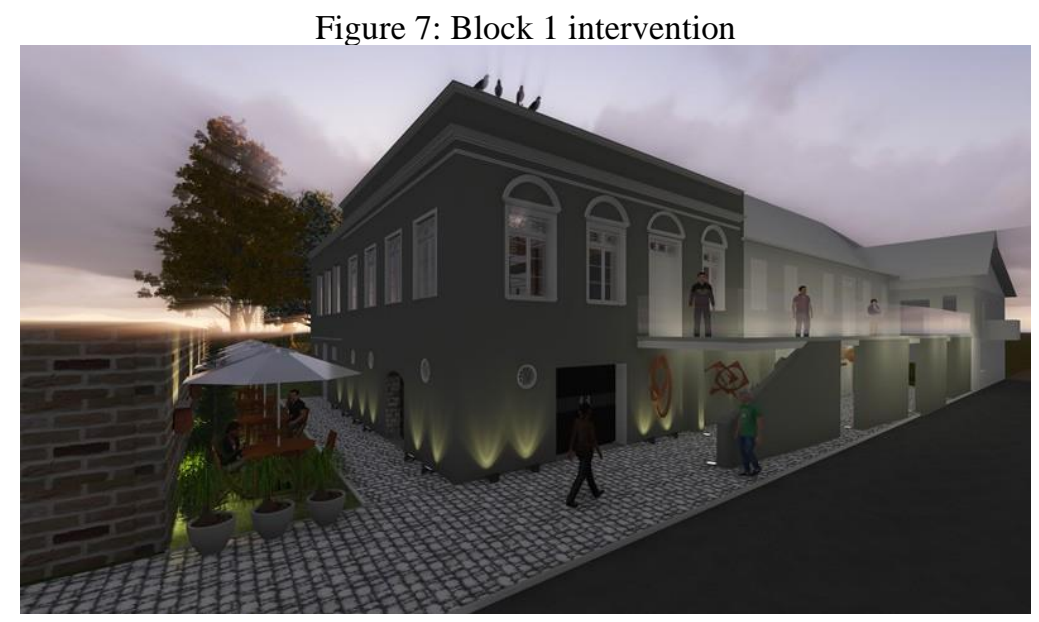


The removal of the internal walls, the stabilization of the ruins of the external walls and the insertion of new construction elements will, again, give stability to the building. The intention is to transform it into a Brewery and the Museum of Craft Beer, knowledge and activities brought by German immigrants.

Figure 8: Internal images of the intervention proposal Block 1

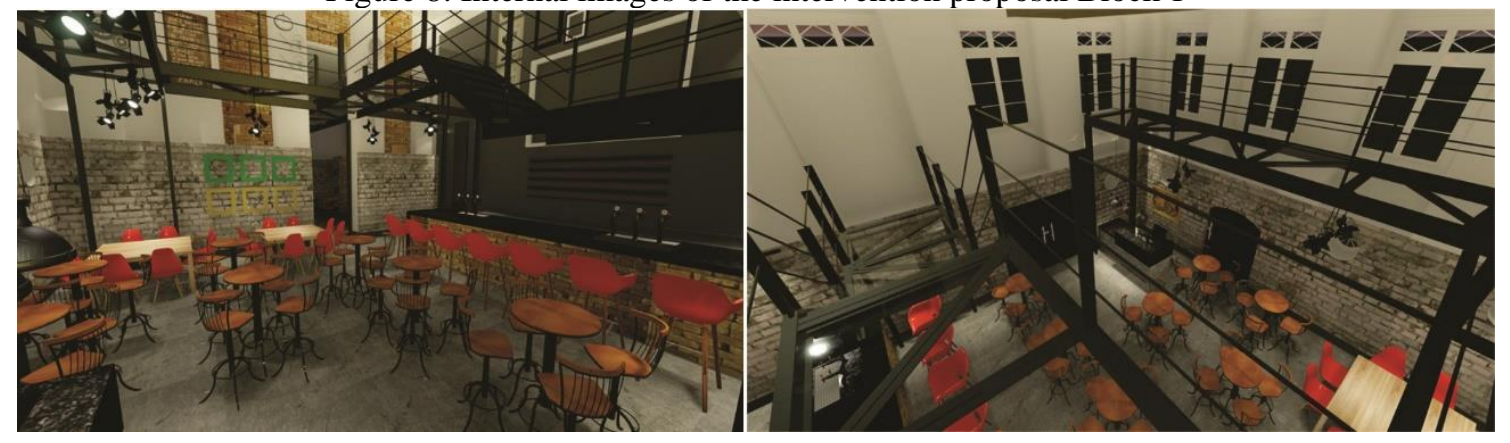

The valorization of local customs must be a priority in this type of intervention, where the precariousness of the state of conservation of the patrimony is of uncertainty the option for the investment of resources for the work.

\section{CONCLUSION}

"The "cultural heritage" is in people's minds and its existence is only guaranteed when it is used
consciously by individuals, as a basis for interaction in social life, for the enrichment and
development of individual and collective life, for the strengthening your identity, your self-
esteem, your decision-making and self-determination." (HORTA, 2000 / A. P.17)

The basic elements of this methodology are objects, products that are socially constructed in the course of the evolution of communities, and their decoding, emphasizing the maxim that only what is known, recognized and referred to people is preserved. It is a dynamic and continuous process, which seeks to raise awareness and deepen people's critical eye towards a new reading of the world and history.

This action will represent a milestone in the policy and practices for the defense of the material and immaterial cultural heritage that is intended to be consolidated in the municipality, opening perspectives for an integrated preservation plan. 


\section{BIBLIOGRAPHY}

(1) Fonte: http://historiasvalecai.blogspot.com.br/2011/02/1109-dona-amalia-ruschel-e-o-cinemana.html

BRAMBATTI, Luiz E., Estrada Rio Branco: O Caminho da Emancipação - Caxias do Sul, RS: Quatrilho Editorial, 2015. 160p.

HERÉDIA,Vania. A Imigração Européia no Século Passado: O Programa de Colonização no Rio Grande do Sul em: http://www.ub.edu/geocrit/sn-94-10.htm

HORTA, Maria de Lourdes Parreiras em Guia Básico de Educação Patrimonial - Brasília. IPHAN 1999

PELLANDA, Ernesto. Aspectos gerais da colonização italiana no Rio Grande do Sul. em: Álbum comemorativo do $75^{\circ}$ aniversário da colonização italiana no Rio Grande do Sul. Porto Alegre: Globo, História, cultura e memória: 180 anos de imigração alemã: Teutônia e Westfália/RS, julho de 2004. - São Leopoldo: Oikos, 2005. 355p. 